\title{
IQCJ wt Allele
}

National Cancer Institute

\section{Source}

National Cancer Institute. IQC) wt Allele. NCI Thesaurus. Code C98106.

Human IQCJ wild-type allele is located in the vicinity of 3q25.32 and is approximately 303

$\mathrm{kb}$ in length. This allele, which encodes IQ domain-containing protein J, plays a role in protein binding. A fusion gene resulting from a read-through of this gene and its downstream neighbor, the SCHIP1 gene, may be associated with the propagation of nerve impulses. 